\title{
One Nation, One Tax: How the Goods and Services Tax (GST) have Impacted the Indian Economy
}

\author{
Ishant Chawla* \\ Student, Symbiosis Centre for Management Studies, Pune, India \\ *Corresponding author: ishantchawla37@gmail.com
}

\begin{abstract}
GST is a single national uniform tax levied across India on all goods and services. In GST, all Indirect taxes such as excise duty, value-added tax (VAT), etc. will be subsumed under a single regime. Introduction of the Goods and Services Tax (GST) expected as a significant step towards a comprehensive indirect tax reform in the country, which would lead India for its economic growth. The implementation of GST will lead to the reduction in the product prices throughout the business cycle. The country's taxation system has improved with the help of GST and the government should take more efforts to training and educating public. Necessary modules should be integrated in the education sector related to GST. The Proposed study is designed to know the impact on GST on Indian Economy with the Help of Its individual effect on different sectors. The Study is Exploratory in nature and Secondary Data has been used for the study. The data is collected from different Journals, Periodicals, Newspapers and Internet.
\end{abstract}

Keywords: CGST, GST, SGST, TAX, VAT.

\section{Introduction}

Goods and Services tax (GST) is a value added tax implemented in India on 1st July 2017. GST is only the indirect tax that directly affects all sections of our economy. GST in India is implemented in the fields of manufacture, sale and consumption of goods and services. GST is considered to be as the greatest reform in the aspect of indirect taxation since 1947.The GST is aimed at creating a single unified market that will benefit both corporate sector and economy. It considers as a significant step towards the economic growth of the country and is also expected to create a business friendly environment, as price level and hence inflation would come down overtime as a uniform tax is applied. The enforcement of the tax was for the long term benefit. Only few sectors received the immediate benefit from the implementation of Goods and Services Tax (GST). The long term benefit requires the patience of citizens. Where one sector in the country faces a positive aspect, on the other hand, the other sector faced the negative aspect. This study is focused on studying the effects of GST on different sectors of the Indian economy which was found to be positive as well as negative depending upon the nature of industry. GST affect all the sectors except petroleum product, milk and a few others. The study also aims to know the advantages and disadvantages of GST in Indian Scenario.

\section{Literature Review}

(Meenakshi, 2018), explains the major impact of introducing GST in India is the transformation in the fiscal structure of the Indian federal setup. It also explains that the fiscal right of the states and centre to deal with goods and services independently will be taken away and both the Governments have to depend on each other's for managing goods and services tax in future.

(Dani, 2016), Studied "Impact of Goods and Service Tax (GST) on Indian Economy" and found out that GST would help in simplifying the current indirect tax structure and remove inefficiencies. Further mentioned that GST is applicable and successful in over 150 countries, but it may falter in India due to likely inflation and also its impact on certain industries like telecommunication.

(Abhishek Kumar Yadav, 2018), this study evaluates that increase in economic activity resulting in increase in growth and new employment opportunities will directly benefit the urban poor. Further concluded that by exempting basic goods of daily consumption from GST and reducing price of goods the GST regime ensures to contribute towards economic growth of the country.

(Upashi, 2017), concluded that GST impact is neutral and positive on different sectors of the economy. Cost of services is going to increase with the result of increase in taxes from $15 \%$ to $18 \%$. The overall effect of GST on Indian economy would be positive.

(Poonam, 2017), states that GST plays a crucial role in the system of indirect taxation. By combining central and state tax system the cascading and double taxation could be reduced. After introduction of GST, the tax burden of consumers can approximately be reduced to $25-30 \%$. Further stated, this type of taxation will surely facilitate economic growth.

(Kiran Ajeev, 2019), concluded that the government should take more efforts to training and educate public. After two and half years of GST the satisfaction level has not reached the expectation of all Governments, consumers and business. Further stated, GST rates should be set according to global rates so that India becomes a preferred competitive destination which 
will give a boost to 'Make in India' initiative.

(Kumar D. C., 2017), reviewed that GST is expected to create a business friendly environment. Further analysed, GST would impact adversely on the real estate market. It would reduce demand by about $12 \%$ and add up to $8 \%$ to the cost of new houses.

(Pooja S. Kawle, 2017), explained implementation of GST in Indian framework would essentially lead to economic development. Further explained, GST will give a boost to Foreign Investment and "Make in India" campaign, export /manufacture activity, generation of more employment, leading to reduced poverty and increased GDP growth.

\section{Research Gap}

The above literature review has identified certain gaps in the knowledge regarding The Impacts of GST.

- Gap 1: Lack of research has been done on consumer perception towards GST.

- Gap 2: Lack of analysis of impacts of GST on sectors like Banking, Telecommunication.

- Gap 3: A detailed analysis of impacts on small business is still missing.

\section{Research Objectives}

After reviewing various research papers related to the impacts of GST on Indian economy. I learned how one taxation system can affect the whole country's economy. The research objective is to understand the concept of GST imposed in India, examine its features and impact it creates on the whole Indian economy. The second objective is to study the effect of this taxation system on different sectors like Manufacturing, Service, etc. and the changes in the business growth in different sectors caused due to GST. And also study and analyse the benefits of GST on economy, business, industry and consumer and perception of different people like consumers, manufacturers, traders, employees on the implementation of GST and provide suggestions and recommendations regarding GST.

\section{Research Methodology}

The purpose of this study is to figure out how the implementation of Goods and Services Tax (GST) has impacted the Indian Economy. Since this is a descriptive type of research we have gathered secondary data through various sources such as journals, articles published online and offline on various newspapers and websites. To analyse the data, statistical tools, such as correlation has been used to determine whether a relationship exists between the two variables and if yes, how significant it is. Moreover, the study on the flow of a product from a manufacturer to consumer with and without GST has been showed to depict the difference.

\section{Impacts}

The imposition of GST had various impacts on the different sectors of the economy which directly or indirectly impacts the country's GDP. The positive as well as negative impact on the economy and on various sectors which are as follows:

\section{A. Impact of GST on Indian Economy}

Goods and Services Tax (GST) is extremely useful for the economy of India for a long term basis. The reason for the benefit of the GST is due to the uniformity of taxes. It merges all the indirect taxes which were prevailing in India during the Value Added Tax (VAT).

As per the Indian manufacturing and trading industry, the total tax component is around $30 \%$ of the product cost. Due to the impact of GST, the taxes have gone down. So, the end consumer has to pay lesser taxes. The reduced burden of taxes has enhanced the production and growth of the manufacturing and trading industries.

- Impact on transaction costs: There has been a significant reduction in the transaction cost. According to the respondents, GST has been a major breakthrough in the interstate movement of goods and it is a good and simple tax. After the introduction of e-way bills, the hassles of earlier regime has almost been removed. This has enhanced the ease of doing business in the regime of indirect taxation.

- Impact on costs of raw material: GST has removed the cascading effect of taxes. This has sufficiently reduced raw material costs and the production costs.

- Impact on sales: One Nation one tax, has given traders and manufacturers freedom to choose the vendors, suppliers, among others with the best prices irrespective of the location as the GST rate is same everywhere in the country and requires very minimal paperwork. This has resulted in the increase in efficiency and supply.

- Impact on labour efficiency: More than 50\% of logistics effort and time is saved as GST has ensured removal of multiple checkpoints and permits at state border checkpoints. This has resulted into more road hours and faster delivery; thus increasing labour efficiency.

- Impact on price cost margins: GST have resulted into competitive pricing and economies of large scale due to easier procedures and low costing. This has made the manufacturers and traders more competitive and increased their profitability.

Summing up the whole, the implementation of GST has given a boost to all the manufacturing and service sectors of India, increased the profitability, lowered the production costs which overall helped in increasing the country's GDP. Goods and Services Tax (GST) will help the Indian economy on a long term basis.

\section{B. Impact of GST on Banking Sector}

- The banking sector became more expensive, previously 
the tax on all the services relating to the banking was $15 \%$ but after the enforcement of Goods and Services Tax (GST), the tax rate on all the banking service was increased to $18 \%$.

- After the implication of GST, the money transaction, whether it was internally or externally, between the two different banks is done by imposing the tax. Before the GST, it was free.

\section{Impact of GST on Telecom Sector}

The implementation of GST sees the slab rate increase from $15 \%$ to $18 \%$ this increases the overall cost to telecommunication service providers, which will ultimately be passed on to the customer. In addition to this, the tax rate on domestic mobile manufacturers has been increased from $6 \%$ to $12 \%$ making locally manufactured mobile handsets costlier than imported ones, since the tax rate for imported handsets has been brought down from $18-27 \%$ down to $12 \%$. This adversely affects the Make in India scheme, which contributed almost $80 \%$ of locally assembled phones.

The implementation of GST sees the slab rate increase from $15 \%$ to $18 \%$ this increases the overall cost to telecommunication service providers, which will ultimately be passed on to the customer. In addition to this, the tax rate on domestic mobile manufacturers has been increased from $6 \%$ to $12 \%$ making locally manufactured mobile handsets costlier than imported ones, since the tax rate for imported handsets has been brought down from $18-27 \%$ down to $12 \%$. This adversely affects the Make in India scheme, which contributed almost $80 \%$ of locally assembled phones.

The implementation of GST sees the slab rate increase from $15 \%$ to $18 \%$ this increases the overall cost to telecommunication service providers, which will ultimately be passed on to the customer. In addition to this, the tax rate on domestic mobile manufacturers has been increased from $6 \%$ to $12 \%$ making locally manufactured mobile handsets costlier than imported ones, since the tax rate for imported handsets has been brought down from $18-27 \%$ down to $12 \%$. This adversely affects the Make in India scheme, which contributed almost $80 \%$ of locally assembled phones.

- The implementation of GST sees the tax rate increases from $15 \%$ to $18 \%$ which will increase the overall cost to telecommunication service providers, which will ultimately be transferred to customers.

- The implementation adversely affects the Make in India scheme, which contributed almost $80 \%$ of locally assembled phones. The tax rate on domestic mobile manufacturers has been increased from $6 \%$ to $12 \%$ making locally manufactured mobile handsets costlier than imported ones, since the tax rate for imported handsets has been brought down from $18-27 \%$ down to $12 \%$.

\section{Impact of GST on Textile Sector}

After the implementation of Goods and Services Tax (GST), all readymade garments which range up to Rs. 1000 are exempted from the terms and clause of the Goods and Services Tax (GST) and where the garments are branded ranging above Rs. 1000 then $12 \%$ of tax will be levied upon them. Goods and Services Tax (GST) has shown its positive impact upon the textile and readymade garments. They are benefited from this new scheme of tax.

\section{Research Hypothesis}

Table 1

Research hypothesis

\begin{tabular}{|l|l|l|}
\hline Independent Variable & Dependent Variable & P-Value \\
\hline Goods and Services Tax (GST) & GDP of India & 1.241440 \\
\hline
\end{tabular}

The P-Value is 1.241440, which is a value close to 1 .

Therefore, with respect to the P-Value, since it is close to " 1 " it can be concluded that alternate hypothesis prevails and we reject null hypothesis.

\section{Results of Data Analysis and Interpretation}

\section{A. Results of Calculated Correlation between GST \& GDP}

Correlation coefficient $=0.606429$

Since it is a positive value we can say that the relationship between Goods and Services Tax Revenues and the GDP of India has positive relationship. The value is very close to 1.0 , which represents a very strong relationship.

\section{B. Flow of GST from Manufacturer, Wholesaler, Retailer and Customer}

The impact with and without GST with relevance of saving Table 2

Data analysis

\begin{tabular}{|l|l|l|l|l|}
\hline Quarter & Year & GDP Rate & GST Revenues(crores) & GDP of India (crores) \\
\hline July-September (Q2) & $2017-18$ & 6.47 & $2,11,269$ & $32,32,072$ \\
\hline October-December (Q3) & $2017-18$ & 7.64 & $2,61,427$ & $33,14,801$ \\
\hline January-March (Q4) & $2017-18$ & 8.18 & $2,67,954$ & $34,91,719$ \\
\hline April-June (Q1) & $2018-19$ & 7.10 & $2,93,085$ & $33,59,162$ \\
\hline July-September (Q2) & $2018-19$ & 6.20 & $2,84,885$ & $34,32,553$ \\
\hline October-December (Q3) & $2018-19$ & 5.59 & $2,93,073$ & $35,00,033$ \\
\hline January-March (Q4) & $2018-19$ & 5.67 & $3,06,327$ & $36,89,674$ \\
\hline April-June (Q1) & $2019-20$ & 5.24 & $3,14,092$ & $35,35,267$ \\
\hline July-September (Q2) & $2019-20$ & 4.42 & $2,92,203$ & $35,84,335$ \\
\hline October-December (Q3) & $2019-20$ & 4.08 & $3,02,055$ & $36,42,748$ \\
\hline January-March (Q4) & $2019-20$ & 3.09 & $3,13,781$ & $38,03,601$ \\
\hline June-August (Q1) & $2020-21$ & -23.92 & $2,64,838$ & $26,89,556$ \\
\hline
\end{tabular}


the cost of producing an item:

Table 3

Manufacturer to Wholesaler

\begin{tabular}{|c|c|c|}
\hline Particulars & Without GST & With GST \\
\hline Raw materials cost & 700 & 700 \\
\hline Add:- Cost of Production & 300 & 300 \\
\hline Manufacturer Price & 1000 & 1000 \\
\hline Add: Excise Duty (12\%) & 120 & - \\
\hline Total & 1120 & 1000 \\
\hline Add:- VAT@ 14\% & 156.8 & - \\
\hline Add:- CGST@ 9\% & - & 90 \\
\hline Add:- SGST@ 9\% & - & 90 \\
\hline Invoice Value & 1276.8 & 1180 \\
\hline
\end{tabular}

Table 4

Wholesaler to Retailer

\begin{tabular}{|c|c|c|}
\hline Particulars & Without GST & With GST \\
\hline Cost of Goods to Wholesaler & 1276.8 & 1180 \\
\hline Add:- Profit Margin @ 10\% & 127.7 & 118 \\
\hline Total & $\mathbf{1 4 0 4 . 5}$ & $\mathbf{1 2 9 8}$ \\
\hline Add:- VAT@ 14\% & 196.63 & - \\
\hline Add:- CGST@ 9\% & - & 116.82 \\
\hline Add:- SGST@ 9\% & - & 116.82 \\
\hline Invoice Value & $\mathbf{1 6 0 1 . 1 3}$ & $\mathbf{1 5 3 1 . 6 4}$ \\
\hline
\end{tabular}

Table 5

Retailer to Customer

\begin{tabular}{|c|c|c|}
\hline Particulars & Without GST & With GST \\
\hline Cost of Goods to Retailers & 1601.13 & 1531.64 \\
\hline Add:- Profit Margin @ 10\% & 160.11 & 153.16 \\
\hline Total Value & $\mathbf{1 7 6 1 . 2 4}$ & $\mathbf{1 6 8 4 . 8}$ \\
\hline Add:- VAT@ 14\% & 246.57 & - \\
\hline Add:- CGST@ 9\% & - & 151.63 \\
\hline Add:- SGST@ 9\% & - & 151.63 \\
\hline $\begin{array}{c}\text { Total Price of item that reaches to } \\
\text { customer }\end{array}$ & 2007.81 & 1988.06 \\
\hline Cost Saving (in Rs.) & - & $\mathbf{1 9 . 7 5}$ \\
\hline
\end{tabular}

The implementation of GST has led to the reduction in the product prices throughout the business cycle from the manufacturer to the end consumer. However, there is a subsequent reduction in cost of product.

\section{Conclusion}

The aim of the government was to bring India in an umbrella of one tax promoting the "One Nation One Tax" system.
Implementation of GST substituted the regime of Value Added Tax (VAT) in India. With the imposition of Goods and Service Tax (GST) was a big task in a country like India where new changes are not easily accepted. It was a complex system to understand at first but later it is coming out as a long term benefit for the country. There are the various sectorial impacts of Goods and Services Tax (GST). Some sectors show a positive impact while others show a negative impact. Due to a long term benefit scheme, there is a less immediate positive impact on Indian society and economy. However, it is expected that there is an expectation of the growth of the Indian Gross Domestic Product (GDP). The only thing is required to have patience and sincerely following the rules and regulations for uplifting the country's economy.

\section{References}

[1] Abhishek Kumar Yadav. (2018). Indian Goods and Services Tax: A Review of its Introductory Stage and its Possible Contribution Towards Sustainable Economic Development. International Journal of Management Studies, 5(3(4)), 84-91.

[2] Arpit Shailesh, D. T. (2016). A study on impact of goods and services tax on Indian economy: A key tax reform. International Journal of Commerce and Management Research, 2(10), 76-80.

[3] Chaurasia, S. P. (2016). Role of Goods and Service Tax in the growth of Indian Economy. International journal of science technology and management, 5(2).

[4] Dani, S. (2016). A Research Paper on an Impact of Goods and Service Tax (GST) on Indian Economy. Bus Eco J.

[5] Gupta, N. (2014). Goods and Service Tax: It's Impact on Indian Economy. International Research Journal of Commerce Arts and Science, 5(6), 126-133.

[6] Khurana \& Sharma, A. (2016). Goods and Services Tax in India -A Positive return for indirect tax system. International Journal of Advanced Research, 4(3), 500-505.

[7] Kiran Ajeev, S. T. (2019). A Study on Impact of GST: Business Review. International Journal of Control and Automation, 12(6), 337-357.

[8] Kumar, D. C. (2017). GST in Indian Economy: It's Benefits and Impact. GST in Indian Economy: It's Benefits and Impact, 6(11), 759-761.

[9] Meenakshi, B. (2018). Impact of GST on Indian Economy. International Journal of Engineering and Management Research (IJEMR), 8(2), 143148.

[10] Pooja S. Kawle, Y. (2017). GST: An economic overview: Challenges and Impact ahead. International Research Journal of Engineering and Technology, 4(4), 2760-2763.

[11] Upashi, R, "Study on effect of GST on different secors in India," Elk Asia Pacific Journal of Finance and Risk Management, 8(4), 2017. 